\title{
A Late Ayyubid Report of Death Found at Quṣayr al-Qadīm ${ }^{1}$
}

\author{
Anne Regourd
}

\section{Reconstruction and Dating}

This article presents a 'report of death' document unearthed in 2003 in Quṣayr al-Qadìm on the Red Sea coast of Egypt by David Peacock and his team from the University of Southampton. ${ }^{2}$ Roughly 1,040 fragments of paper documents in Arabic were collected from Qușayr al-Qadìm between 1999 and $2003,{ }^{3}$ some with writing on them, others without. The edition of and commentary on this text appears below in appendix 1.

The document consists of two fragments and has been partially reconstructed (inv. $\mathrm{n}^{\circ}$ PA0386, and PA0381, see text 1, and fig. 2.1 and 2.2). Both were found in 2003 in the same archaeological trench and context (trench 13, context 5500). Both had been rolled up and use the same high-quality paper, thick and smooth. ${ }^{4}$ Laid lines are not obvious, but cannot be entirely counted out either. Both use the same open and regular script which, considering this was an administrative document (see parts II and III) and therefore probably written by an official, can be taken as a sample of the script of a dīwān. ${ }^{5}$

1 I would like to thank Frédéric Bauden, University of Liège, for his useful remarks on my reading of the private letter.

2 The reports of the excavations are available online at www.arch.soton.ac.uk/Research/ Quseir/. A survey of the excavations has been published by David Peacock and Lucy Blue, see Peacock and Blue, Myos Hormos. For the Islamic burial sites of Quṣayr al-Qadīm, see ibid., 'Trench 1A' 157-159.

3 For an overview of the Southampton collection of the Quṣayrī fragments, see Regourd, Trade. A book is in preparation, which will contain the edition of ca. 50 items. The study of these fragments has been made possible within the framework of the Reconstructing the Quseiri Arabic Documents (RQAD) project, funded by the UK's Arts and Humanities Research Council (AHRC).

4 I consulted the original documents kept by the Egyptian Antiquities Service at the end of 2004. I wish to thank the Service for giving me the four-week authorisation necessary for this work.

5 A very closed script for the basmala is displayed in al-Qalqashandì (d. 821/1418), Șubḥal-a shāa,

(C) ANNE REGOURD, 2015 | DOI:10.1163/9789004284340_003

This is an open access chapter distributed under the terms of the prevailing CC-BY-NC License at the time of publication. 
The same trench and context yielded another fragment bearing a witness formula (inv. PA0388, see text 1, 'witness clause' and fig. 2.4). It too had been rolled up, although it has traces of folding along the longer side (ca. $2 \mathrm{~cm}$ from the bottom edge). The paper has lost its starch. Its length of $11.1 \mathrm{~cm}$ roughly corresponds to the length of the central part of the report of death $111.3 \mathrm{~cm}$, fig. 2.2). The script is different from text 1 , suggesting that the three fragments form together an original document, rather than a copy.

Trench 13 is an Islamic rubbish deposit, quite probably from Mamluk times, but consisting mainly of Ayyubid material. ${ }^{6} A, B$ and $C$ were found in the same context as a paper from the "archives" of the Abū Mufarrij company. These archives have been reconstructed by Li Guo in his study on the Arabic documents from Qușayr, ${ }^{7}$ and all the dated evidence in his material is from the first four decades of the seventh/thirteenth century, namely, the period of the reigns of the Ayyubid sultans al-Malik al-Ādil (r. 596-615/1200-1218) and his son al-Malik al-Kāmil (r. 615-635/1218-1238). In addition, the formula seems to follow those of the Cairo Geniza papers dating from the seventh/thirteenth century (see appendix 2), which would also place it in this time frame.

Six reports of death of Jewish women from the Geniza collection, published by Geoffrey Khan, were also all written according to the same formula. ${ }^{8}$ "Their dates fall within the last three quarters of the seventh/thirteen century, spanning the Ayyubid and early Mamluk periods (from 621-629/1224-1231 to 697/1298)." The reports of death from other collections that I have been able to locate were found at Qașr Ibrīm, but are late and have a different purpose. ${ }^{10}$

The missing part of the document is reconstructed according to the model of the documents found in the Geniza. An idea about the width of the Quṣayr al-Qadìm document is given by the piece bearing the basmala $(22.5 \mathrm{~cm})$, so that we can probably reconstruct the missing part between $A$ and $B$ on side 1 as having contained the name of the dead person and the date of his death.

3:132, al-șurra al-ū $\bar{u}$, assuming the printed text is correct compared to the manuscripts. The section is devoted to the script of the basmala in the dīwann al-insh $\bar{a}$.

6 For trench 13, see Peacock and Blue, Myos Hormos 172-173.

7 Guo, Commerce.

8 P.GenizahCambr. 125, 126, 127, 128, 129, 130. No. 129 is mentioned by Rabie, The financial system 130 and n. 4. No. 130 is mentioned in Goitein, A Mediterranean society 2:321, 473-480.

$9 \quad$ P.GenizahCambr., p. 473 .

10 Hinds and Ménage, Qașr Ibrīm 68, 32-33, dated 1082/1672; ibid., 75, 48-49, dated 110o/1689. Werner Diem presented a Report of Death in his contribution to the Fourth International Society for Arabic Papyrology Conference, in Vienna, March 26-29, 2009, called, "Some remarkable Arabic documents from the Heidelberg collection." 
If my reasoning is correct, the deceased is a Muslim. Every published report from the Geniza specifies the day on which the death occurred. But the date as well as the reasons of the death do not appear in our document. Here the place where the dead person died is mentioned as being săhil al-Qusayr, i.e. 'the coast of Qușayr,' referring to 'the anchorage of Qușayr."11 It can simply mean that the man died in the anchorage of Qușayr al-Qadim or close to it, or the death could have happened on a ship. Besides Qușayr, săhil al-Qușayr appears frequently in the addresses of the Qusayr letters. ${ }^{12}$ It also sometimes appears in the text of the documents. ${ }^{13}$

\section{The Qușayrī Report of Death Bearing Mention of Heirs and the Dēwān al-mawārīth al-ḥashriyya}

Khan suggests that these reports of death were "presumably addressed to the dīwān al-mawärith al-hashriyya,"14 the office of intestate successions, which kept a register of deaths. ${ }^{15}$ Ibn Mammātì (d. 6o6/1209) gives a precise statement about the conditions under which this office was entitled to (a part of) the inheritance: "If there were no heirs, or the heir or heirs were not entitled to the whole of the inheritance, the whole estate in the first case, or its residue in the second, would go to the bayt al-mäl. As the sole Fatimid concession to remain in force, the share of the absent heir would be kept in trust in the treasury until his return."16

11 Cf. the discussion in Regourd, Arabic. Access to the coast around Qușayr al-Qadīm is difficult because of a barrier of coral, which is, however, discontinuous at the level of Qușayr al-Qadīm (Peacock and Blue Myos Hormos 8, fig. 2.2). The recent excavations have revealed evidence of industrial activity in particular what has been interpreted as the repair and/or construction of boats in the channel from the sea to the south (ibid., 111-115). The 'natural' elements that made it a place for the ships to stop are evident.

Guo, Commerce 10, 157; 13, 165; 16, 173; 18, 176; 25, 197; 26, 199; 55, 251; For the documents found in Qusayr between 1999 and 2003, see Regourd, Trade on the Red Sea.

13 Guo, Commerce 52, 246, recto l. 3, and 54, 249, recto l. 1; and also in 70, 287, recto l. 3, "sāhil" being translated as "the aforesaid port."

14 P.GenizahCambr., 125, 473.

15 al-Qalqashandī, Șubḥ 4:33.

16 Rabie, The financial system 127-128, who summarises Ibn Mammātìs Kitāb Qawānīn aldawāwin, 319-325. However, an early document, dating to the 1 st-2nd/7th-8th centuries, which was produced in a time close to when Shafiite law was being shaped, refers to the case of a woman who died without heirs and the legal arrangements that followed from it, 
From the time of the Ayyubids, the definition of those having a right to the inheritance was, following Shafi ite and Malikite doctrine, restricted. The office charged with investigating and determining the succession of those without heirs on behalf of the treasury was precisely the office of intestate successions. ${ }^{17}$ This system continued under the Mamluks with the dīwān being clearly linked to the dīwān al-amwāl within the structure of the dīwāns. ${ }^{18}$ Outside Cairo and Fustạt further dīwāns were located in the major cities of Egypt. ${ }^{19}$ Ayyubid reports of death bear the same formula whatever the religious identity of the deceased, as we saw above. And the inheritances for Jews were directly supervised by the same authorities as inheritances for Muslims during our period. ${ }^{20}$ In conclusion, the diwwan was supposed to register only the deaths of those with taxable legacies. ${ }^{21}$ But in each published report of death in the Geniza, the deceased does have some heirs to his estate, as does the deceased of the Qușayri document. The next question then is how the dīwān functioned in practice?

Rabie observes that "Baybars [Mamluk Sultan, r. 1260-1277] used to levy a tax on a deceased person's estate even if there were heirs," and reaches the conclusion that "it is very probable that the officials of the mawārith had to report each deceased case immediately and separately." Rabie then refers to one of the Geniza's report of death documents, dated 682/1284, i.e. during the reign of Sultan Qalāwūn (r. 1279-1290), which was later published by Khan who, in his edition, referred to Rabie's analysis. ${ }^{22}$ Generally speaking, for the published Geniza reports of death, which usually concern Jewish women, Khan refers to al-Nuwayri's (d. 732/1332) Nihäyat al-arab, where it is written that "the heads of the dhimmis had to notify the government of every death in their communities." ${ }^{23}$ This is confirmed by the works of Ibn Taghrī Birdī (d. 874/1470)

namely that in cases without legal heirs, the inheritance (here estate) goes to the highest religious authority (Liebrenz, Eine frühe arabische, commentary to ll. 5-6).

17 Cf. al-Qalqashandī, Subh, 4:33; Tyan, Histoire de l'organisation 549, in comparison with Fyzee, The Fatimid law 61-69, for the Fatimid law of inheritance.

18 Cf. Gottschalk, Dīwān (II.- Egypte) 330.

19 Dols, The Black Death 171, 181.

20 Goitein, A Mediterranean society 3, 277-278; Dols, The Black Death 180, 175.

21 Dols, The Black Death 175.

22 Rabie, The financial system 130; P.GenizahCambr. 129, 478.

23 al-Nuwayrī, Nihàyat al-arab 242-243. Dols, who used the records of the mawārīth to assess urban depopulation after epidemics in the fourteenth and fifteenth centuries, on the other hand, argued that: "the dīwāns [referring to the Dīwān al-mawārith al-hashriyya] of the major cities registered only the deaths of those who died with taxable legacies. Cairo 
and al-Qalqashandì (d. 821/1418), who describe the general functioning of the dìwān during the Mamluk period. ${ }^{24}$

As far as the understanding of the Qușayrī document is concerned, which dates to the first four decades of the seventh/thirteenth century, Rabie does not discuss evolutions in the functioning of the mawāith under the Ayyubid rulers in as much detail as he does those changes under the Mamluks. He has, however, carefully studied taxes and other sources of revenue going to the treasury and discusses the functioning of the Māl al-mawārith al-hashriyya. ${ }^{25}$

Ibn Mammāti's description of the general functioning of the dīwann suggests that during the Ayyubid period the mawärith authorities decreed that the burial of the dead could take place only after their officials have been informed, suggesting that at that time each death was registered. ${ }^{26}$ It seems also that a kind of co-ordination existed between the police and the judiciary, with the police registering the death and then reporting to the qã $\bar{d} \bar{\imath}$ in the quarter where the deceased lived. ${ }^{27}$ Ibn Mammātī describes the customary procedure following a person's death: the undertaker informed the mawärith official who in turn determined the identity of the heirs. ${ }^{28}$ The Quṣayri document, if we assume that the witness clause is part of it, looks more like a legal document produced by the office of a $q \bar{a} d \bar{\imath}$.

Also relevant is an iqrär document from the al-Haram al-Sharif collection dating to the second half of the eighth/fourteenth century, i.e. under Mamluk rule. ${ }^{29}$ In this document a "Turkish woman [called] Yulqațlū declares in writing

and Fusțāt had separate dīwāns and included the deaths of Christians and Jews as well as Muslims for both these cities" (Dols, The general mortality 397). Dols also takes into account changes of the rules concerning dhimmīs who had converted to Islam in order to divert money from the legal heirs to the treasury (Dols, The Black Death, $175 \mathrm{ff}$.; Dols, The Black Death $397 \mathrm{ff}$.).

24 As discussed by Lutfi, who criticised Dols's argument especially because he did not define what he meant by "taxable legacies" and did not substantiate other aspects of his argument (Lutfi, Al-Quds 16-17).

25 Rabie, The financial system $127 \mathrm{ff}$.

26 Ibn Mammātī, Qawānīn al-dawāwìn 324-325, mentioned by Lutfi (Al-Quds 14) who analyses the reasons.

27 Lutfi, Al-Quds; Scanlon, Housing 185.

28 Ibn Mammātī, Qawānīn al-dawāwīn 325, mentioned by Lutfi (Al-Quds 14-15).

29 Published in Lutfi, Al-Quds. For the general functioning of the dīwān al-mawārith alhashriyya in Jerusalem during the Mamluk period through the documents of al-Haram al-Sharif, i.e. the administration of the estate from the inventory of the inheritance and its selling, until the administration of the following income for the dīwān, see Müller, Qā $\bar{l}_{\bar{l}}-$ Gericht und Rechtsadministration $391 \mathrm{ff}$. Some comparisons are made with the situation 
that her husband is her sole legal heir." ${ }^{30}$ While the Haram collection includes both private and public documents, the iqrärs belong to the private legal document type. That is to say, they were issued on behalf of private individuals and the judiciary. ${ }^{31}$ This particular document had been drafted before the death of the Turkish woman. Lutfi underlines the fact that it represents a different use of the iqrär, compared to the five other pieces that she published together with it, namely its use as a legal document. It has been written up according to the Sharia, and its formalistic structure is similar to the others. But what makes it a 'legal document, she explains, is its judicial registration: "Because the iqrār of Yulqațū involved a unique case of inheritance, the legal document had to be certified by the qā $\bar{\imath} \bar{\imath}$ so that the husband's legal right would not be contested in the future. Thus unlike the other iqrārs dealt with in this paper, the present one is a judicial iqrär, witnessed and certified in court." ${ }^{32}$ Lutfi then discusses the judicial registration marks on its recto and the ishhäd on its verso, both witnesses to its being part of the judicial proceedings. ${ }^{33}$ This document belonged to the strategies used by individuals to avoid attempts of all sorts to divert money when it was possible according to the Sharia. ${ }^{34}$

Meanwhile our document may be considered in another way, that is to say in connection with the abusive practices by or through the office of intestate successions. The mawārith authorities were open to corruption as early as Saladin's reign (r. 1174-1193), says Rabie, who adds: "There exists a manshūr written by $[q \bar{q} \bar{d} \bar{\imath}]$ al-Fādil which reprimands a mushārif for his greed, and warns him that the sultan knows of and is worried about the defects of the administration of the mawārith." ${ }^{35}$ According to Rabie again, during the Mam-

in Cairo and, especially, the relation between this institution and Bayt al-mäl. Cf. Lutf, Al-Quds 18-19.

30 Lutfi, A study of six; Lutfi, A documentary source $315,278-287$, and plate viI, recto and verso, the quotation itself is taken from page 286 .

31 Lutfi, A documentary source 149.

32 Lutfi, A documentary source 286.

33 Lutfi, A documentary source $281 \mathrm{ff}$.

34 Müller deals in his Chapter v with estates under judicial and public control (Müller, Qā Gericht und Rechtsadministration $357 \mathrm{ff}$.). He then studies the iqrärs of estate inventories legalised through ishhād (witness citation) by a $q \bar{a} \underline{d} \bar{\imath}$ and in what cases these were valid

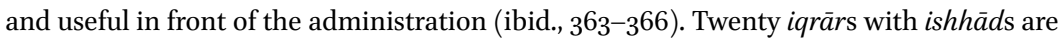
mentioned, containing dispositions of goods belonging to couples (ibid., 363 no. 1501). The procedure authenticating an inheritance by iqrär was especially prevalent in the case of a single heir (ibid., 365).

35 Rabie, The financial system 128, and note 2, quoting Rasā̉il al-Quā dīal-Fädil, Ms. Add. 25757, fol. 1or-v; also Lutfi, Al-Quds 14-15. 
luk period abusive practices also prevailed, but at another level. The mawärith became a way for the rulers to collect extra money, which was then conveyed to them through Bayt al-māl. Rabie mentions in particular that the Mamluk sultan Quțuz (r. 1259-126o), while preparing troops to fight the Mongols, collected money from the estates of the deceased inhabitants for the treasury, without considering the number of heirs or the size of the estate. The absence of the heirs at time of death of a relative was also a pretext for abusive seizures. ${ }^{36}$ On the other hand, persons without legal heirs, but having daughters for instance, found strategies to avoid the seizure of their property by the dīwān al-mawārith after their death, in particular through the waqf institution, as early as the Ayyubid period. ${ }^{37}$ This shows that people could find different ways to get around the obstructive measures of the dīwän al-mawärith. The Quṣayrī report of death could then have been produced because of a dispute, between the administration and individuals, as a witness to the existence of heirs.

\section{A Reused Report of Death}

After our document was used as an administrative document, it was re-employed to write a letter (see text 2, and fig. 2.3). Here, the report of death, as well as the witness clause, was written on one side, keeping the other side blank (both $A$ and $c$ are indeed blank on the other side). The paper was rolled up with the written part of the letter on the inside, which confirms that the report of death was the first text to be written. $A$ was also rolled up, surely from left to right and with the text inside, but the way $A$ was rolled up is different from $B$. The report of death document was probably cut up before it was reused, that is to say cut before the letter was written on the back of $B$. The upper edge of $B$ does not fit with the edge of $A$ on the lower side. We know from the report of death that part of the document is missing. But it can clearly be observed that fragment $A$ was cut with a sharp tool. In addition, the edges of $B$ are neither clean-cut nor straight and we observe that the letter itself had been cut off at a later stage (see the text missing on the left side). We can then postulate one more step between the original shape of the letter and how it appears now. Moreover, $B$ is not as long as $A$. The beginning of the letter $(B / 2)$ corresponds roughly to the middle of the formula of the report of death, which is on the

36 Rabie, The financial system 131 and n. 3, and also Tyan, Histoire de l'organisation.

37 Rabie, The financial system 128-129, n. 1. 
other side. And as is usual, the name of the sender appears on the upper left side, close to the left edge.

That administrative reports of death were subsequently used to write something else on the other side has been previously observed. The bulk of reports of death published by Khan for example follow this model. No. 128 has been reused to write Hebrew liturgical poetry on the other side. The back of no. 129 has a business account, mainly in Judaeo-Arabic with "Coptic" numerals (some are written as well at the top and right of the report of death). The other side of no. 130 contains Arabic pen trials. Finally, no. 131, a formulary for reports of death, contains a letter in Arabic on the verso. ${ }^{38}$ We might remark from an anthropological point of view that writing a letter on a report of death does not seem to bring bad luck! Generally speaking the formulary, even with its witness clauses, covers only one page, leaving the other side blank. ${ }^{39}$

The practice of recycling the archives of the administration has been studied by Petra Sijpesteijn for Abbasid Egypt, ${ }^{40}$ by Frédéric Bauden for Mamluk chancery documents ${ }^{41}$ and by Jonathan Bloom for Yemen in the time of Imam Yahya in the early twentieth-century. ${ }^{42}$ If our hypothesis is correct and the fragment bearing the witness clause is part of the report of death (text 1, 'witness clause' and fig. 2.4), it should be an original since the administration only kept summaries of documents if at all. Dominique Valérian describes the importance of individuals involved in a case retaining documents, given the authorities' practice of not keeping copies: "Dans sa plainte, déposée à Gênes, la victime déclare que les deux malfaiteurs ont brûlé ces documents pour effacer les traces de leur dette et il ajoute qu'ils l' ont fait en sachant que les notaires musulmans ne conservent pas les documents qu' ils ont."43

There is one final remark to be made concerning the document. At least the complete document, i.e. the report of death re-used for writing a private letter, both mentioning Quṣayr and found in Qușayr shows that the one who died in Qușayr was connected with a family settled in Qușayr.

\footnotetext{
$38 \quad$ P.GenizahCambr. 128, 129, 130, 131.

39 Cf. the three other reports of death published by Khan in P.GenizahCambr. 125-127.

$40 \quad$ Sijpesteijn, Coptic and Arabic.

41 Bauden, The recovery.

42 Bloom, Paper before print 79-80, after Abbott, The rise 13-14.

43 Valérian, Bougie, port maghrébin 311-312.
} 


\section{Appendix 1}

\section{Text 1. Qusayr-Report of Death-Beginning of the 7th/13th Century Arabic Text}

$[A]$ (Fig. 2.1)

$$
\begin{aligned}
& 1
\end{aligned}
$$

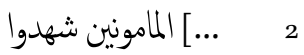

$$
\begin{aligned}
& 3
\end{aligned}
$$

$[B / 1]($ Fig. 2.2$)$

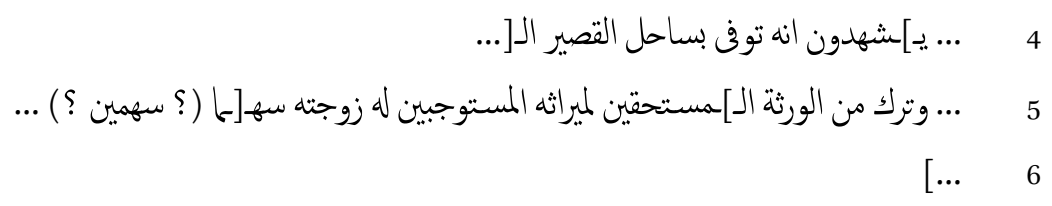

Translation

$1 \quad[A]$ In the name of God, the Merciful and Compassionate-God bless our Lord Muhammad, his family and his companions, and save him!- $[\ldots$

$2 \quad$...] the trustworthy have witnessed

3 [the death of so-and-so, the son of so-and-so, on such-and-such a day of such-and-such a month, in such-and-such a year.]

$4 \quad[B / 1]$ They witness that he died on the coast of Qusayr [...

5 ... He left by way of] heirs having right to his inheritance who deserve it, his wife a lo[t $(?$, or two?), ...

6 ...]

\section{Commentary}

4. There are only two dots under the first letter; what seems to be a third dot is in fact a hole in the paper. The three dots on the top are on the original. The $n \bar{u} n$ at the end of the first word, yashhadūna, has a dot, as does the nūn of the following word, annahu.

5. Sahman: a reading, which does not explain the ligature between the $h \bar{a}$ and the sin (compare with المستحقين and المستوجبين). Another possibility, following the Geniza model, is that the name (ism) of the wife follows her mentioning as an heir; but in this case the alif of ism would have been omitted. 
Witness Clause [c]

Arabic Text (Fig. 2.4)

$$
\begin{aligned}
& \text { • [المأمون يعلم صحة ذلك } \\
& 2 \\
& 3
\end{aligned}
$$

Translation

1 [The trustworthy recognises the validity of this.]

$2 \quad$ Written for him, Ibn 'Abd al-Ghaffār [ibn 'Abd Allāh (?)] ordered it and witnessed it

3 on its date.

\section{Commentary}

1. The same expression is found in Khan repeatedly; however, a slight change has been made here, in order to be consistent with the beginning of the report of death, which refers to al-ma'mūn, instead of al-mamlük (compare with P.GenizahCambr.131).

2. Witness names are usually given with at least one generation of kunya (P.GenizahCambr.131).

Text 2. Qusayr-A Letter-Beginning of the 7th/13th Century-[B / 2] Arabic Text (Fig. 2.3)

$$
\begin{aligned}
& 1 \\
& 2 \\
& 3 \\
& 4
\end{aligned}
$$

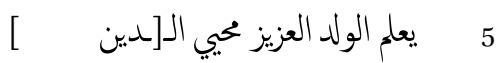

Right Margin

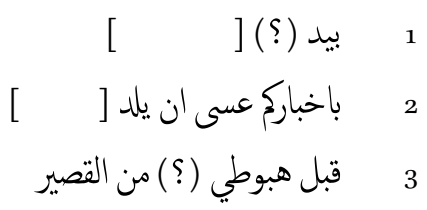




\section{Translation}

1-2 (From) his father Husayn ibn Riḍān-God maintain both in life!-

3 In the name of God, the Merciful, the Compassionate. God bless [our Lord, the Prophet Muhammad!]

4 and the one, I was missing being close to, but what [to do]? I ...[(Your) father]

5 is writing to inform (his) dear son Muhyī al-[Dīn ] ]

\section{Right Margin}

1 to the care of (?) [so-and-so ... ] ]

2 to hear from you all. Let us hope that he gives birth [ ]

3 before I set down (?) coming from Qușayr.

\section{Commentary}

1. The paper has some internal dark spots which appear to be dots, but are not. This is a speculative reading.

3. The two dots at the last end of the line appear on the original as part of the writing. The tașliya has been shortened as is usual in the Qușayrī documents; the sender is mentioned at the top of the letter, close to the left edge.

4. The dot under kayfa appears on the original.

\section{Right Margin}

The stroke which appears under the three lines of text does not correspond to any writing and seems to be connected with the text on the other side, quoted here as text 1 . The reading of lines 1 and 3 is a best guess. 


\section{Appendix 2. The Geniza Model—7th/13th Century}

T-S Ar. 39.277 (After P.GenizahCambr. 131)

Text

$$
\begin{aligned}
& 1 \\
& 2 \\
& 3 \\
& 4 \text { 4 المسما فلان بن فلان فلما تحققوا ذلك كتبوا خطوطهم به }
\end{aligned}
$$

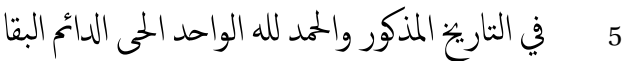

Witness Clauses

$$
\begin{aligned}
& 1 \\
& 2 \\
& 3 \\
& 4 \\
& 5 \\
& 6 \text { و واما بقرابة عارف وكتب فلان بن فلان رايس اليهود يومئذ }
\end{aligned}
$$




\section{Figures}

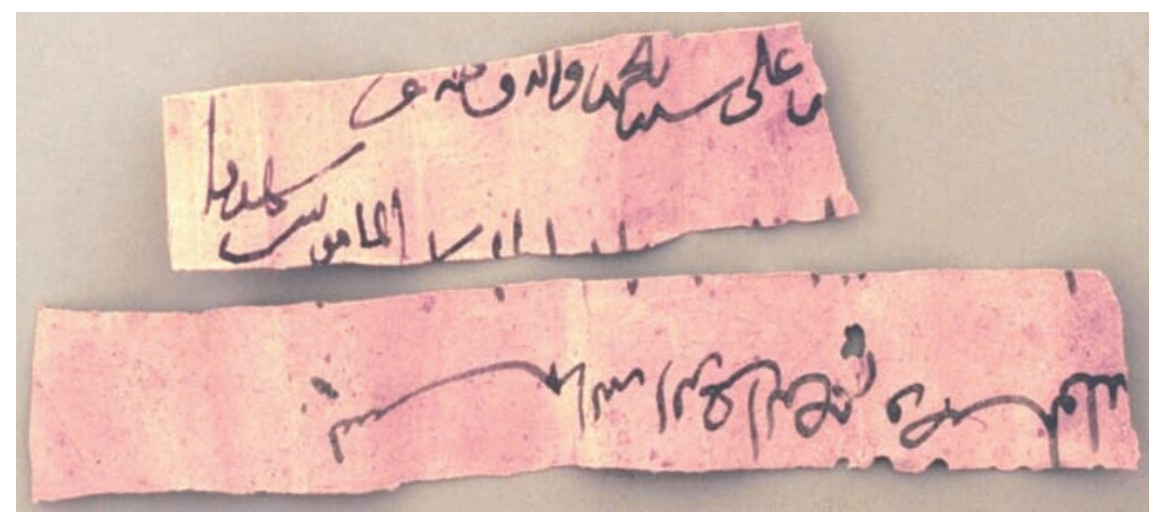

FIGURE 2.1 A INV. PAO386. (C) University of Southampton, Qușayr al-Qadim project

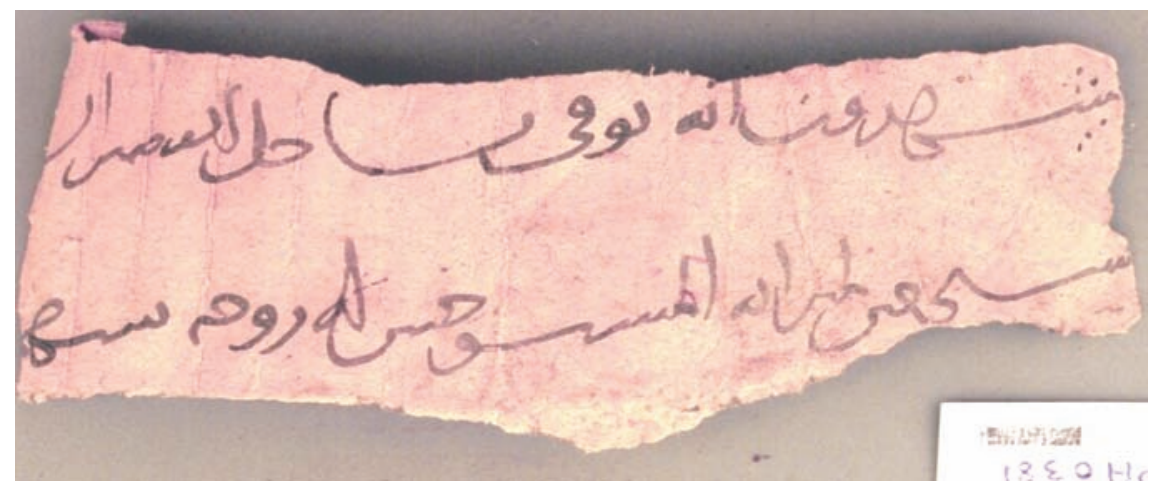

FIGURE 2.2 B/1 INV. PA0381. (C) University of Southampton, Qusayr al-Qadim project 


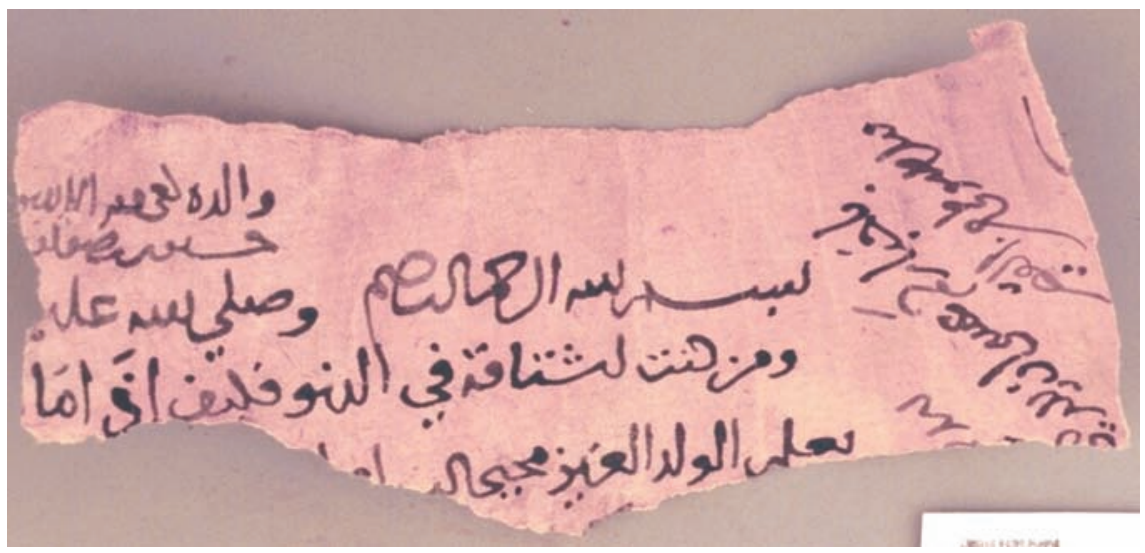

FIGURE 2.3 B/2 INV. PAo381. (C) University of Southampton, Qușayr al-Qadim project

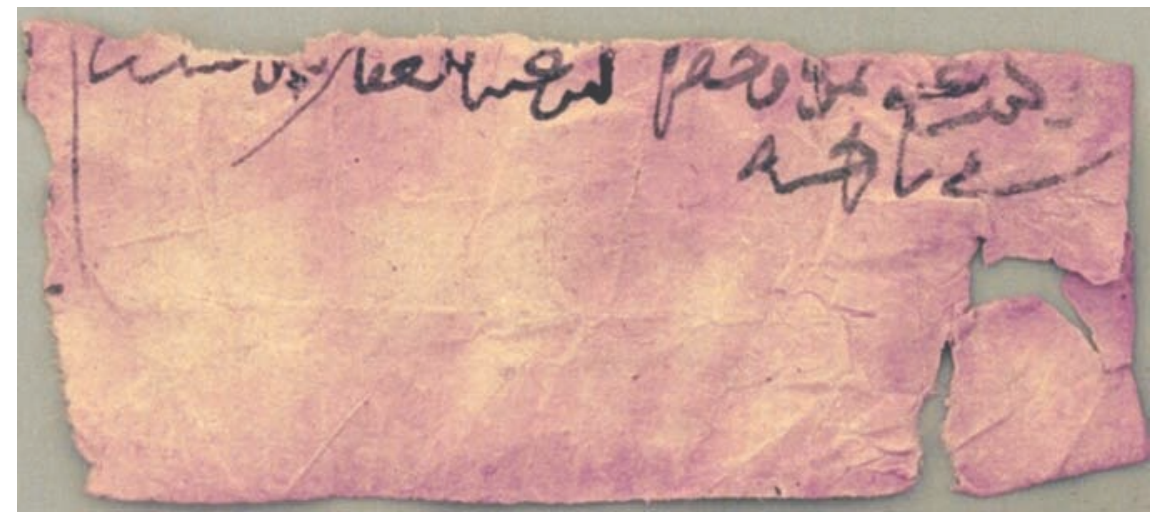

FIGURE 2.4 C INV. PAOz88. (C) University of Southampton, Qușayr al-Qadim project 


\section{Bibliography}

\section{Primary Sources}

Ibn Mammātī, Kitāb Qawānīn al-dawāwīn, ed. A.S. 'Ațiyya, Cairo 1943.

al-Nuwayrī, Nihāyat al-arab fi funūn al-adab, Cairo 1350/1931.

al-Qalqashandī, Subḥ al-a sh ā fì șinā'at al-inshā’, ed. M.H. Shams al-Dīn, Beirut 1407/ 1987.

\section{Secondary Sources}

Abbott, N., The rise of the North Arabic script and its Kur'änic development, with a full description of the Kur'ān manuscripts in the Oriental Institute, Chicago 1939.

Bauden, F., The recovery of Mamluk chancery documents in an unsuspected place, in M. Winter and A. Levanoni (eds.), The Mamluks in Egyptian and Syrian politics and society, Leiden and Boston 2004, 59-76.

Bloom, J.M., Paper before print. The history and impact of paper in the Islamic world, New Haven and London 2001.

Dols, M.W., The Black Death in the Middle East, Princeton 1977.

- The general mortality of the Black Death in the Mamluk empire, in A.L. Udovitch (ed.), The Islamic Middle East, 700-19oo: Studies in economic and social history, Princeton 1981, 397-428.

Fyzee, A.A., The Fatimid law of inheritance, in $S I$ (1958), 61-69.

Goitein, S.D., A Mediterranean society, Berkeley, Los Angeles and London 19671993. 6 vols.

Gottschalk, H.L., Dīwān (II.- Egypte), in Encyclopaedia of Islam. New Edition, 1965, 327-331.

Guo, L., Commerce, culture and community in a Red Sea port in the thirteenth century. The Arabic documents from Qușayr, Leiden 2004.

Hinds, M. and V. Ménage, Qașr Ibrìm in the Ottoman period: Turkish and further Arabic documents, London 1991.

Hourani, A. and S.M. Stern (eds.), The Islamic city: A colloquium, Oxford 1970.

Liebrenz, B., Eine frühe arabische Quittung aus Oberägypten, in Archiv für Papyrusforschung (2010), 294-314.

Lutfi, H., A study of six fourteenth century iqrārs from al-Quds relating to Muslim women, in Journal of the Economic and Social History of the Orient 26 (1983), 246294.

. Al-Quds al-Mamlūkiyya: A history of Mamlūk Jerusalem based on the Haram documents, Berlin 1985 .

A documentary source for the study of material life: A specimen of the Haram estate inventories from al-Quds in 1393 A.D., in Zeitschrift der Deutschen Morgenländischen Gesellschaft 135, 2 (1985), 213-226. 
Müller, C., Qāḍ̂̄-Gericht und Rechtsadministration in Jerusalem. Studie der mamlūkischen Dokumente des Haram al-Sharîf, Habilitation degree, Halle-Wittenberg 2006, II: $5,181-182$; V: 1, 357-366, and 4, 391-403.

Peacock, D.P. and L. Blue, Myos Hormos-Qusayr al-Qadim. Roman and Islamic ports on the Red Sea. Volume I: Survey and excavations 1999-2003, Oxford 2006.

Rabie, H., The financial system of Egypt A. H. 564-741 / A.D. 1169-1341, London 1972.

Regourd, A., Trade on the Red Sea during the Ayyubide and the Mamluk period: The Qușayr paper manuscript collection 1999-2003, first data in Proceedings of the Seminar for Arabian Studies 34 (2004), 277-292+15 fig.

—. Arabic language documents on paper, in D.P. Peacock and L. Blue (eds.), Myos Hormos-Quṣayr al-Qadim. Roman and Islamic ports on the Red Sea. Vol. II: The finds from the 1999-2003 excavations, Oxford 2011, 339-344.

Scanlon, G.T., Housing and sanitation: Some aspects of medieval public service, in A. Hourani and S.M. Stern (eds.), The Islamic city: A colloquium, Oxford 1970, 179-194. Sijpesteijn, P.M. Coptic and Arabic Papyri from Deir al-Balāicizah in P.Schubert (ed.), Actes du 26e Congrès international de papyrologie (Genève 2010), Geneva 2012, 707-714. Tyan, E., Histoire de l'organisation judiciaire en pays d'Islam. 2nd ed., Leiden 1960, 179-194.

Valérian, D., Bougie, port maghrébin. 1067-1510, Ph.D. dissertation, École française de Rome 2006. 